\title{
Estimation of Stature from Footprint Length
}

\author{
Janarthanan $\mathbf{R}^{1}$, Muthamizh Selvan ${ }^{2}$ \\ ${ }^{1}$ Assistant Professor, Department of Forensic Medicine, Vinayaka Mission's Medical College \& Hospital, Karaikal, \\ ${ }^{2}$ Assistant Professor, Department of Forensic Medicine, Mahathma Gandhi Institute of Medical Sciences and \\ Research, Pondicherry
}

\begin{abstract}
The human foot is studied for various reasons in forensic departments, by anthropologists, anatomists etc. Footprints are of immense value in a crime scene in establishing the personal identity and in a potential link between the perpetrator and the scene of crime. Identification of a person is of prime and foremost importance in both civil and criminal cases. Time is a critical factor in crime scene investigation, so rapid identification of suspect is very important. Here, in our study, the aim is to estimate the stature of individuals based on their footprint lengths among the students (Both male and female students between the age group 18 to 22 years) 50 male and 50 female students, studying in Rajarajeswari Medical College and Hospital, Bengaluru. that the footprint length help us in estimating the stature of an unknown individual which will be helpful in investigation of various crimes. Also not much difference is statistically noted in the stature estimated by right and left footprint length in both the sexes.
\end{abstract}

Keywords: Stature; Foot print length; Identification.

\section{Introduction}

To establish the identity of a person if alive or expired is called identification of a person. The Latin word, 'idem' known as "the same" 1 is from which the word identification has its origination. Determination of identity of a person in case of emergency disasters like bomb blast, hurricane, train wreck, flight fall, earthquake etc. will not be an easy task for an autopsy surgeon to rectify the clarification of identity of a person from an amputated body part. 2 stature, in the pharmacological aspect is also important for to determine the nutritional range and for the estimation of pharmacokinetic measures of a person. The identification of a male or a female is made easier if the stature of a person is determined in any sort of investigation to determine the identity of a person. 3

\section{Corresponding Author:}

Janarthanan R

Assistant Professor, Department of Forensic Medicine, Vinayaka Mission's Medical College \& Hospital, Karaikal - 609609 .

\section{Aims and Objectives of the Study}

To estimate the stature of individuals based on their footprint lengths

\section{Material and Method}

Materials used are as follows:

1. Printers black ink,

2. Non- breakable glass plate,

3. White sheets,

4. Roller,

5. Pencil,

6. Measuring scale,

7. Measuring tape,

6. Calculator and

7. Proforma.

Collection of Footprints

Both male and female students those who are studying in Rajarajeswari Medical College and Hospital, 
Bengaluru -560074 , between the age group 18 to 22 years will be included in the study. The consent of those students will be obtained in a pre-designed and pre-tested pro-forma consisting the objectives of the students after explaining them the aim and objective of the study.

A glass plate of $24 \times 24$ inches cleaned and smeared uniformly with painters ink will be kept on the floor.

The students after washing and drying their feet will be asked to stand on the smeared glass plate first and then, on two separate white sheets so that prints of right foot and left foot will be transferred on these white sheets separately. In this way footprints of all the individuals will be recorded. The footprint length will be measured from the heel to the tip of extension of longest toe.

Then all the students will be asked to stand bare foot and erect on the floor with their heel and occiput attached to the wall where markings for measuring height are already made. The students will be asked not to move the head. A thin plate is kept horizontally at the vertex of the head. Then the height will be measured from heel to the horizontal thin plate. Height of the individual will be measured in $\mathrm{cm}$ to the nearest $\mathrm{mm}$.

The data collected is analyzed statistically by using descriptive statistics, namely percentage and standard deviation. The results will be predicted using SPSS version 20, if required, using leniar regression equation for stature estimation and to assess the co-relation between the footprint length and stature, Pearlson's correlation coefficient method will be adopted.
PLACE OF STUDY: Rajarajeswari Medical College and Hospital, Bengaluru-560074.

DURATION OF STUDY: 1 year and one month.

SAMPLE SIZE: 100 students(50 males and 50 females)

\section{Inclusion Criteria}

1. Both male and female students who are studying in RajaRajeswari Medical College and Hospital, Bengaluru-560074 between the age group 18 and 22 years.

2. Students of both sexes.

3. Age group between 18 years to 22 years.

\section{Exclusion Criteria:}

1. Students other than the age group 18 to 22 years.

2. Students with any abnormality of foot/lower limb.

3. Students with any spinal abnormality.

4. Students with any endocrinal disorders.

\section{Sampling Method}

Convenient sampling method.

\section{Results}

Table-1: Correlation between Right Foot Print Length, Left Foot Print Length and Stature in Male Students

\begin{tabular}{|l|l|l|l|l|l|l|}
\hline Variable & N & Mean \pm SD & Range & $\begin{array}{l}\text { Cor. } \\
\text { Coeff. } \\
\text { r-value }\end{array}$ & $\begin{array}{l}\text { Reg. Coeff. } \\
\text { b-value }\end{array}$ & Reg. Equation \\
\hline $\begin{array}{l}\text { RFPL } \\
\text { Actual Ht }\end{array}$ & 50 & $\begin{array}{l}24.7 \pm 1.25 \\
173.5 \pm 6.64\end{array}$ & $\begin{array}{l}22.3-28.0 \\
156-196\end{array}$ & +0.659 & 3.49 & $\mathrm{Ht}=86.89+3.49$ (RFPL) \\
\hline $\begin{array}{l}\text { LFPL } \\
\text { Actual Ht }\end{array}$ & 50 & $\begin{array}{l}24.8 \pm 1.29 \\
173.5 \pm 6.64\end{array}$ & $\begin{array}{l}21.6-28.6 \\
156-196\end{array}$ & +0.0652 & 3.34 & $\mathrm{Ht}=90.15+3.34$ (LFPL) \\
\hline
\end{tabular}

RFPL $=$ Right Footprint Length LFPL $=$ Left Footprint Length 
$\mathrm{Ht}=$ Height Comparing Right Footprint Length and Left Footprint Length P - 0.0

Table no. 5 represents the height of 50 male students and the co-relation between the right and left foot print length.

The average of the right footprint is slightly larger than the left.

A relavant co-relation between the right footprint with stature $(r=0.659)$ and the left footprint length with stature $(\mathrm{r}=0.0652)$. The difference in co-relation coefficient is statistically significant (p-0.000). To determine the stature based on any given right or left footprint length can be made with this significant corelation.

When one such right footprint length is given, the stature can be estimated by the regression equation.

$$
\mathrm{Ht}=86.89+3.49(\mathrm{RFPL})
$$

When one such left footprint length is given, the stature can be estimated by the regression equation.

$$
\mathrm{Ht}=90.15+3.34(\mathrm{LFPL})
$$

Table-2: Correlation between Right Foot Print Length, Left Foot Print Length and Stature in Female

\begin{tabular}{|c|c|c|c|c|c|c|}
\hline Variable & $\mathbf{n}$ & Mean \pm SD & Range & $\begin{array}{l}\text { Cor. } \\
\text { Coeff. } \\
\text { r-value }\end{array}$ & $\begin{array}{l}\text { Reg. } \\
\text { Coeff. } \\
\text { b-value }\end{array}$ & Reg. Equation \\
\hline $\begin{array}{l}\text { RFPL } \\
\text { Actual Ht }\end{array}$ & $\begin{array}{l}50 \\
50\end{array}$ & $\begin{array}{l}22.3 \pm 1.125 \\
157.78 \pm 6.65\end{array}$ & $\begin{array}{l}19.8-24.9 \\
144-172\end{array}$ & +0.761 & 4.426 & $\mathrm{Ht}=58.93+4.42(\mathrm{RFPL})$ \\
\hline $\begin{array}{l}\text { LFPL } \\
\text { Actual Ht }\end{array}$ & $\begin{array}{l}50 \\
50\end{array}$ & $\begin{array}{l}22.2 \pm 1.1 \\
157.78 \pm 6.65\end{array}$ & $\begin{array}{l}19.8-25 \\
144-172\end{array}$ & +0.747 & 4.438 & $\mathrm{Ht}=59.08+4.43(\mathrm{LFPL})$ \\
\hline
\end{tabular}
Students

RFPL $=$ Right Footprint Length LFPL $=$ Left Footprint Length

$\mathrm{Ht}=$ Height

Comparing Right Footprint Length and Left Footprint Length P - 0.00

Table no.6 represents the height of 50 female students and the co-relation between the right and left foot print length.

The average of the right footprint is slightly larger than the left.

A relavant co-relation between the right footprint with stature $(r=0.761)$ and the left footprint length with stature $(r=0.747)$. The difference in co-relation coefficient is statistically significant ( $p-0.000)$. To determine the stature based on any given right or left footprint length can be made with this significant corelation.

When one such right footprint length is given, the stature can be estimated by the regression equation.

$$
\mathrm{Ht}=58.93+4.42(\mathrm{RFPL})
$$

When one such left footprint length is given, the stature can be estimated by the regression equation.

$$
\mathrm{Ht}=59.08+4.43(\mathrm{LFPL})
$$




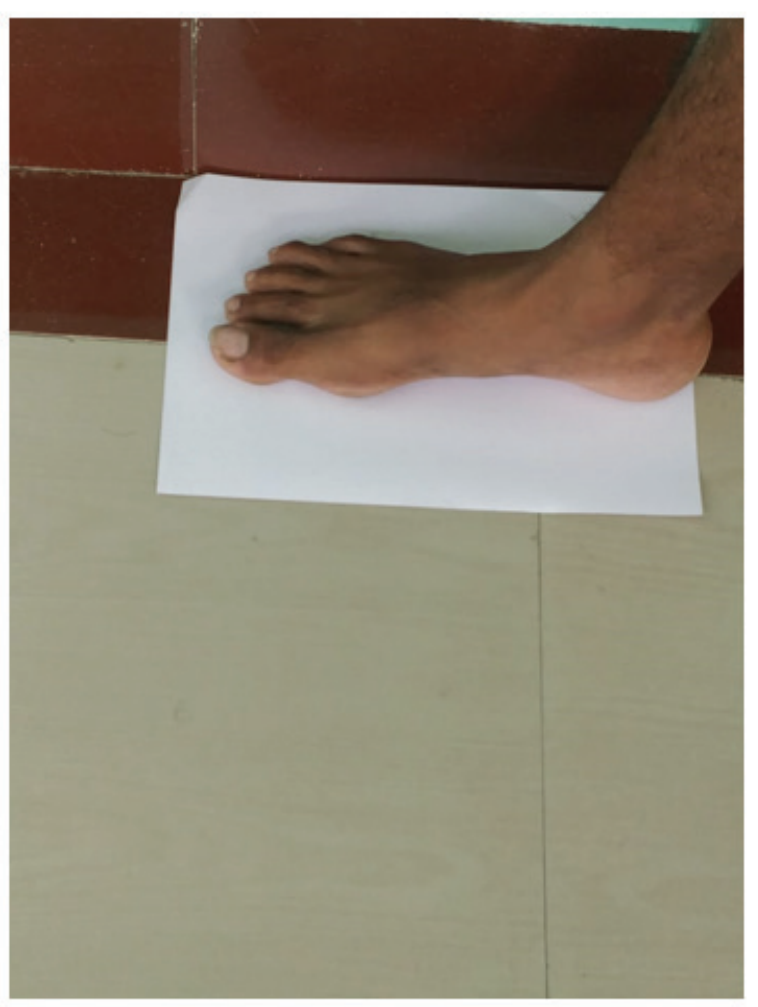

Figure-1: Method of recording footprint

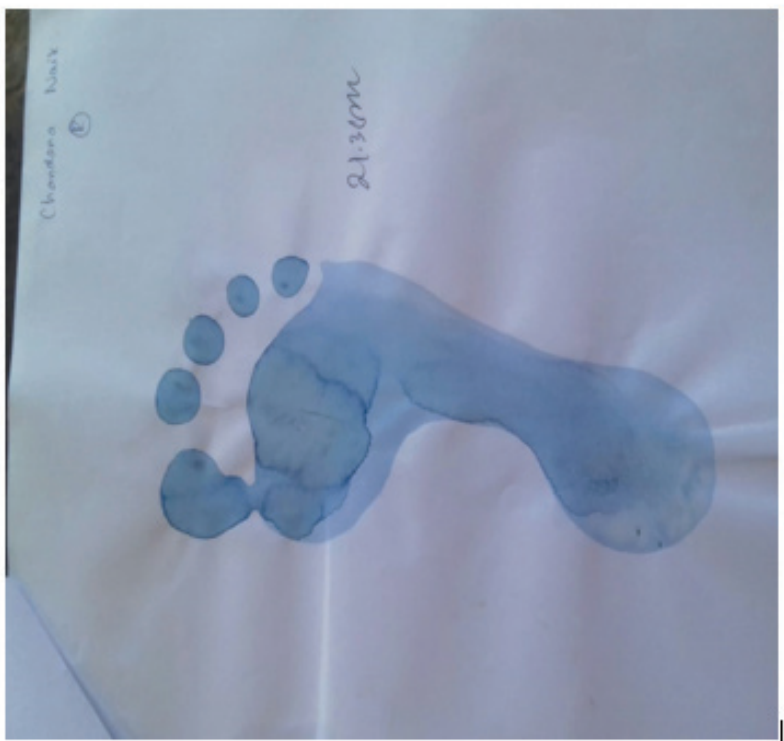

Figure 2. Right footprint of a student

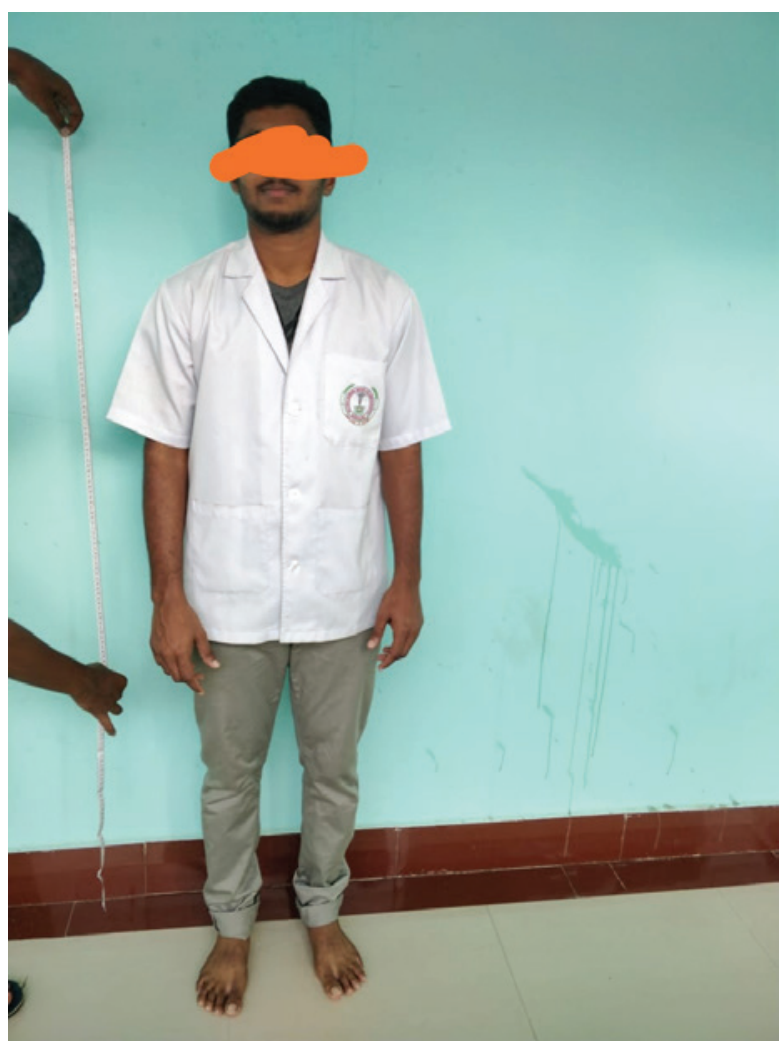

Figure 03. Measuring height of a student

Ethical Clearance- obtained from institutional ethical committe

Source of Funding- Self

\section{Conflict of Interest- Nil}

\section{Discussion}

Stature can be estimated from many parameters of the body parts, also the researches were made on them by many researchers. But very few researchers estimated stature from footprint length. Researchers did their work for footlength in both sexes but for the footprint length is rare. Our study is on both sexes of both right and left footprint length to estimate stature from it.

But in the study done by Devesh VO (2006)4, Danborno B (2008)5 and Vidya CS6, the footprint is lengthier in men than the women which is of same results as our study.

In our study, the footprints of both the foot in both sexes gives the height of an individual approximately for each foot and this is also seen the study made by Theodoros B Grivas7 (2008).

Our study gives the regression equations for both the 
footprint length by which the height can be determined whereas the stature from the known footlength only can be determined by a regression formula in the study made by Abraham Philip8.

In our study, only the length of the longest toe to the tip of the sole is taken to give the height of the student whereas in the work done by Jaydeep Sen (2008)9

The girls are less in height and they have length of their foot also little short than the boys. Also he stated that there is a good relationship which is significant between the height and the length and the breadth of the individuals foot. $(\mathrm{P}<0.01)$.

Separate regressions equations were developed for both the footprints of both the genders in our study similarly, a study which was done only on males which had significance in the footlength and height with a $\mathrm{P}<$ 0.001 by Raju M10 (2009)

Also a similar research results were noted among the individuals of Uttarakhand region by Deopa Deep11 (2010)

\section{Conclusion}

Though the stature and the relationship with their body parameters differ from region, culture nutrition etc., the relationship between foot length and stature is reliable. Still there will be difference in the results in different regions for the same reasons.

The formula concluded in this study is not of cent percent result giving but an approximate stature can be estimated from a person's footprint. Also the people with the mentioned exclusion criteria in this study, their stature cannot be estimated from this formula.

\section{References}

1. Vij K. Identification. Textbook of Forensic Medicine and Toxicology. 5th ed. New Delhi: Elsevier; 2011. pp35-73.
2. Mansur DI, Haque MK, Sharma K, Karki RK, Khanal K, Karna R. Estimation of Stature from Foot Length in Adult Nepalese Population and its Clinical Relevance. Katmandu Univ Med J 2012;37(1):16-9.

3. Ahmed AA. Estimation of Sex from the Lower Limb Measurements of Sudanese Adults. Forensic Sci Int 2013;42:169.

4. Devesh V O, Kuruvilla A, Saralaya KM. Estimation of stature and sex from foot print length using regression formulae and standard foot print length formulae respectively. J Punjab Acad Forensic Med and Toxicol. 2006; Vol 6: p. 5-8

5. Barnabas Danborno, Abraham Elukpo. Sexual dimorphism in hand and foot length, indices, stature-ration and relation to height in Nigerians. The Internet Journal of Forensic Science 2008: 3(1)

6. Vidya CS, Shamasundar NM, Manjunatha, Nitin MD. Study of footprints for sex determination in the South Indian population. Journal of South India Medicolegal Association 2009 Sept; 1(2): 49-52.

7. Theodoros B G, Mihas. Correlation of foot length with height in school age children. J Forensic and Legal Medicine. 2008 Feb; 15(2): 89-95.

8. Abraham Philip. Formulae for estimating stature from foot size by regression method. J Ind Acad For Med, 1990; 12 (2): 57-62.

9. Jaydeep Sen, Sheela Ghosh. Estimation of stature from foot length and foot breadth among Rajbanshi: An indigenous population of North Bengal. For Sci Int 2008 Oct; 181(1): 55.e1-55.e6.

10. Raju M, Vijaynath V, Anitha. Walking bare foot: Print shows stature of male individual. JIAFM 2009: 31(4).

11. Deopa Deepa. Estimation of stature from foot length in Uttarakhand region. Indian Journal of Forensic Medicine and Toxiclogy 2010; 4(1). 